\title{
Knowledge, Attitude and Practices Towards COVID -19 Among University Level Students in Bangladesh
}

\author{
Ferdousi $\mathrm{SS}^{1}$, Ferdousi $\mathrm{S}^{2}$, Rahman $\mathrm{MM}^{3}$, Khan $\mathrm{MH}^{2}$, Rahman $\mathrm{SMM}^{3}$, Fahim $\mathrm{FR}^{4}$, Naafi $\mathrm{SM}^{5}$ \\ ${ }^{1}$ Department of Gynae and Obs, Col Malek Medical College and Hospital, Manikganj, Bangladesh; \\ ${ }^{2}$ Disease Control Unit, Directorate General of Health Services, Dhaka, Bangladesh; ${ }^{3}$ Academic Wing, \\ Institute of Public Health, Dhaka, Bangladesh; ${ }^{4}$ Bangladesh University of Professionals, Dhaka, \\ Bangladesh, ${ }^{5}$ Dhaka Medical College and Hospital, Dhaka, Bangladesh
}

\begin{abstract}
Background: SARS-CoV-2 a highly contagious virus causing the current global pandemic of COVID -19 is transmitted mainly through close physical contact and airborne transmission of respiratory droplets, and associated with significant morbidity and mortality.

Objective: The study was carried out aiming to assess knowledge, attitude and practices (KAP) of university level (medical and nonmedical) students towards COVID-19.

Methods: This online cross-sectional KAP study was carried out among university level students. The questionnaire used consisted of two main sections: demographic and knowledge, attitude and practic es (KAP) towards COVID-19 transmission and prevention. Demographic variables include d gender, age, religion, marital status, type of education. KAP section consisted of 14 questions for assessment of knowledge regarding clinical symptoms, transmission route, vaccine, prevention and cont rol of COVID-19. The link of the online questionnaire was shared with students of three government and one private medical colleges and 8 universities of which 5 government and 3 private through their faculties with an invitation to participating in the study.

Results: A total of 399 students participated in the study, $61.9 \%$ were non-medical and $38.1 \%$ were medical students; males accounted for $62.7 \%$ of the respondents. Knowledge and practice scores were significantly higher in females than in males $(p<0.05)$. KAP scores were significantly higher among medical students compared to non-medical students $(p<0.05)$. Though about $52.1 \%$ of total students had good knowledge, less than $25 \%$ had favourable attitude and $48.6 \%$ had good practices towards preventive measures of COVID- 19 .
\end{abstract}

Conclusion: There is need for more awareness campaign focusing the students to cover their knowledge gaps, motivation for appropriate practices and further improvement of attitude and practices towards preve ntion of COVID-19 transmission.

Keywords: COVID-19, KAP, University level students, SARS-COV-2.

\section{Introduction}

The highly infectious novel corona virus disease that was first identified Wuhan, China, the causative agent was initially named as 2019 novel corona virus (2019-nCOV) which later was renamed as SARS-CoV-2 and the disease it caused was named as corona virus disease $2019(2019-\mathrm{nCOV}){ }^{1,2,3} \mathrm{On}$ the $30^{\text {th }}$ January, 2020, the World Health Organization (WHO) declared that the outbreak constitutes a Public Health Emergency of International Concern (PHEIC) and as global pandemic on the $11^{\text {th }}$ March $2020^{3,4}$ The COVID-19 pandemic is associated with increasing morbidity and mortality and has impacted the lives of the global population. ${ }^{3,5}$ SARS-CoV-2 is an enveloped non-segmented RNA virus. ${ }^{1,6}$ Among the six corona

*Correspondence: Dr. Shammi Sultana Ferdousi, Department of Gynae \& Obs, Colonel Malek Medical College, Manikganj, Bangladesh.

e-mail: drshammi1971@gmail.com; ORCID:0000-0001-9580-3962 viruses known to infect humans generally are responsible for mild respiratory symptoms similar to that associated with the common cold while SARS-CoV-2, SARS-CoV and MERS-CoV are implicated to cause lethal respiratory infection. ${ }^{6}$ Though the natural reservoir of SARS-CoV-2 remains obscure bat has been implicated to be the source of SARS-CoV-2 based on its 96.2\% genomic similarity with the bat corona virus COV Ra T-G $13 .{ }^{6-8}$ The COVID-19 virus is transmitted mainly through close physical contact and respiratory droplets, while airborne transmission is possible during aerosol generating medical procedure. ${ }^{9}$ SARS-CoV-2 invades lower respiratory tract cells using the angiotensin- converting enzyme 2(ACE-2) receptor. ${ }^{10}$ The incubation period of the SARS-CoV-2 1-14 days and individuals with asymptomatic infection were found to spread the disease. ${ }^{11}$ SARS-CoV-2 infection could result in mild to severe respiratory illness (often flu like) 
commonly manifested by dry cough, fever, myalgia and in severe cases by difficulty in breathing and sometimes symptoms referable to other organ system. ${ }^{12}$ Global Health Expert and South Asia governments have expressed concern about the spread of COVID-19 and potential for more than 7.6 million deaths in South Asia if no action taken. ${ }^{5}$ As part of it's preparation for facing the pandemic the Government of Bangladesh had put in place several precautionary measures including limitation of on arrival visa, strengthening the health screening services at the point of entries. On the 1st of February 2020, 312 Bangladeshi returned from Wuhan and this group of returnees were placed under 14 day formal institutional quarantine before being allowed to go home. ${ }^{13}$ Despite of all efforts taken by the country, Bangladesh reported its first case on March 8, 2020 there after each day increasing number of COVID-19 patients were detected. ${ }^{14,15}$ To limit the spread of disease, all educational institutes were declared closed from $17^{\text {th }}$ March 2020. In addition, different stakeholder initiated awareness building programme susing audio-visual methods radio, television, cable network and social media targeting prevention of COVID-19 throughout the country. Human knowledge and behaviour about a disease is often critical for the success in efforts for containing a disease outbreak.

Pandemic situations are often followed by infodemics, large amounts of fabricated, fictitious information circulate on social media relating to mode of infection, the disease itself and means of disease prevention, in such context knowledge and behavior assessment the public is essential for success of awareness programmes. ${ }^{16}$

In the current context, a dearth of information regarding the knowledge, attitude and practices of students towards prevention of COVID-19 exists. Practicing meaningful social distancing, wearing mask, and growing habit of frequent hand washing by soap and water, avoiding spitting, could appear as a critical challenge when students are invited into a new normal way of life. Students are likely to adopt appropriate preventive measures for COVID-19 disease, if empowered by proper information relating to the disease agent, it's mode of entry into human body, risk factors, common disease manifestations, availability of treatment and means of preventing the disease. Therefore, the current study was carried out with the objective to assess knowledge, attitude and practices (KAP) of university level (medical and non-medical) students towards COVID-19 during the rapid rise period of Covid-19 pandemic.

\section{Materials and Methods}

This cross-sectional study was conducted from $11^{\text {th }}$ of July to $10^{\text {th }}$ of August 2020. Data collection was carried out through a Google form based questionnaire that had an interface which explained the objectives of the study, provided assurance to the participant regarding confidentiality and was informed that completing and submitting the form would indicate that he/she was a consenting participant. This study was approved by the IRB of Institute of Public Health, Mohakhali, Dhaka

The questionnaire included a section for demographic information and sections for assessment of KAP (Knowledge, Attitude and Practice). Demographic variables included gender, age, religion, marital status, education, and residence type. KAP section consisted of 14 questions for assessment of knowledge regarding clinical symptoms, transmission route, vaccine, prevention and control of COVID-19, 3 questions for assessment of attitude and another 7 for assessing practice.The knowledge, attitude and preventive practice related questions that were developed using information from WHO COVID -19 advice for the public and other published studies. ${ }^{17,18}$ The estimated sample size for the study was 384. The questionnaire link was sent to faculties of threeprivate and fivegovernment universities, and fourmedical colleges (1 private and3 government) for distributing to their students with a request of prompt response. To minimise the missing data, the participants were requested to fill all the items in the online questionnaire or else could not proceed to the next item. On completion the form, the participants were directed to write their email address and click the submit option. Data collection was closed when responses from 399 participants were obtained. Data retrieved from the online survey were transferred into the Microsoft Excel and then into the Statistical Package for Social Science (SPSS) version 20. For analysis, knowledge, attitude and practice responses were scored. Each correct answer/response was given one (1) point and wrong answer and don't know responses were assigned zero ( 0$)$ point. The total knowledge score for the students varied from 0 (no correct answers) to 14 (all correct answers) while the highest possible scores for attitude could be 3 and 7 respectively. Bloom's cut-off $80 \%$ was used to determine the cut-off points to categorize knowledge as good (score $\geq 11.2$ ) and poor $(<11.2)$; attitude as favorable attitude (score $\geq 2.4$ ) and disfavorable (score <2.4); and practice as good (score $\geq 5.6$ ) and bad (score <5.6). ${ }^{19}$ Thereafter frequencies, percentages and mean scores were 
obtained. Chi-square distribution was used to assess potential statistical relationships between demographic variable and knowledge, attitudes, and preventive practice categories. To detect significant differences in scores between groups t-test or ANOVA was carried out as applicable, $p$-values of less than 0.05 was considered as statistically significant.

\section{Results}

Among the 399 participants who completed the survey forms $62.7 \%$ were male and $83.2 \%$ were 18 to 23 years of age, $84.7 \%$ were Muslim, $38.1 \%$ were medical students and about $62 \%$ were students of universities located in Dhaka city and other districts (table-I).

Table I: Demographic characteristics of the study population $(\mathrm{n}=399)$

\begin{tabular}{ccc}
\hline & Variable & Number (\%) \\
\hline \multirow{3}{*}{ Age (years) } & $18-20$ & $173(43.4)$ \\
& $21-23$ & $159(39.8)$ \\
\multirow{2}{*}{ Gender } & $24-26$ & $52(13.0)$ \\
& $>26$ & $15(3.8)$ \\
Religion & Male & $250(62.7)$ \\
& Female & $149(37.3)$ \\
& Islam & $338(84.7)$ \\
Educational institution type & Hinduism & $51(12.8)$ \\
& Others & $10(2.5)$ \\
& Medical College & $152(38.1)$ \\
& Govt/National University & $168(42.1)$ \\
\hline
\end{tabular}

Responses relating to knowledge, attitude and practice of the students regarding COVID-19 were recorded (table II). Correct responses for each knowledge question varied from 21.3 to $98.2 \%$. The highest correct responses were for the query if the corona virus enters the body through nose eye and mouth (98.2\%) followed by the response to the query regarding the incubation period $(97.0 \%)$ and performed very poorly when asked about the inter-individual distance indicated by social distancing $(21.3 \%)$.

Table II: Knowledge, attitude and practices regarding COVID -19 of the participants ( $\mathrm{n}=399)$

\begin{tabular}{|c|c|c|}
\hline Variable & Question $^{* *}$ & $\begin{array}{l}\text { Number }(\%) \text { of } \\
\text { correct responses }\end{array}$ \\
\hline \multirow{14}{*}{ Knowledge } & COVID is the species of (SARS/MARS/ I don't know) & $299(74.9)$ \\
\hline & Incubation period of COVID virus is (2-10 days/2-14 days/ don't know) & $387(97)$ \\
\hline & Fever, fatigue, dry cough and myalgia are the main symptom of COVID-19 (True/False/ don't know) & $367(92)$ \\
\hline & COVID-19 may spread from infected person not having any symptom/s ( $\underline{\text { True }} / \mathrm{False} /$ don't know) & $358(89.7)$ \\
\hline & Currently there is no effective treatment for COVID-19 (True/False/ don't know) & $305(76.4)$ \\
\hline & Vaccine is not available for COVID-19 ( $\underline{\text { True } / F a l s e / ~ d o n ' t ~ k n o w) ~}$ & $373(93.5)$ \\
\hline & $\begin{array}{l}\text { Which is the best way to prevent the COVID-19 (Stay home for } 14 \text { days/wait until negative test } \\
\text { result/ don't know) }\end{array}$ & $367(92.0)$ \\
\hline & Elderly people having co morbidity likely to suffer from severe COVID-19(True/False/ don't know) & $325(81.5)$ \\
\hline & Use of hand sanitizer is only way to disinfect the hands (True/False/ don't know) & $274(68.7)$ \\
\hline & Children and young adult have no chance to be infected by COVID-19 (True/False/ don't know) & $380(95.2)$ \\
\hline & Isolation of infected people will reduce transmission of infection (True/False/ don’t know) & $380(95.2)$ \\
\hline & Corona virus can enter in the body through nose, eye and mouth (True/False/ don't know) & $392(98.2)$ \\
\hline & $\begin{array}{l}\text { Type of mask fit for general use in COVID situation (surgical mask/N-95/ /don't know) } \\
\text { Social Distance equal to (Minimum } 2 \text { hands } / 3 \text { hands } / 4 \text { hands distance/don't know) }\end{array}$ & $\begin{array}{l}159(39.8) \\
85(21.3)\end{array}$ \\
\hline & Do you agree that smoking can prevent COVID-19? (Yes/No/ don't know) & $341(85.5)$ \\
\hline \multirow[t]{2}{*}{ Attitude } & 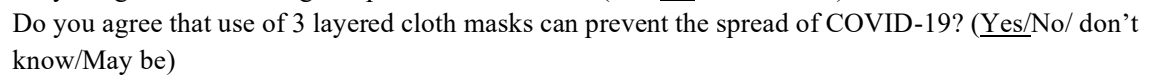 & $115(28.8)$ \\
\hline & $\begin{array}{l}\text { Staying home is the effective measure to control the transmission of COVID ( } \underline{\text { Yes}} / \mathrm{No} / \text { don't } \\
\text { know/May be) }\end{array}$ & $353(88.5)$ \\
\hline \multirow{7}{*}{ Practice } & Do you wear mask when you go outside? ( $\underline{\mathrm{Yes}} / \mathrm{No} /$ Occasionally) & $382(95.7)$ \\
\hline & Do you shake hands with others? (Yes/ $\underline{\mathrm{No}} / \overline{\text { Occasionally) }}$ & $356(89.2)$ \\
\hline & Do you take ginger, lime juice or hot water? (Yes/No/ Occasionally) & $213(53.4)$ \\
\hline & Do you maintain social distance during going out side? ( $\underline{\mathrm{Yes}} / \mathrm{No} /$ Occasionally) & $346(86.7)$ \\
\hline & $\begin{array}{l}\text { Do you gossip/face to face chatting in a group with friends inside house or outside? (Yes/No/ } \\
\text { Occasionally) }\end{array}$ & $271(67.9)$ \\
\hline & Do you perform physical exercise? (Yes/No/ Occasionally) & 199 (49.9) \\
\hline & Do you go to restaurant for hang out with friends or with family? (Yes/No/ Occasionally) & $333(83.5)$ \\
\hline
\end{tabular}

** Responses appear in parentheses \& the appropriate answer is underlined 
Correct responses for each attitude question varied from 28.8 to $88.5 \%$. Only $28.8 \%$ agreed that a 3-layered cloth mask could prevent the spread of COVID-19, $14.5 \%$ thought that smoking could prevent COVID-19 and $11.5 \%$ did not think that staying at home was effective in controlling the transmission of COVID-19. Favourable practice for each practice question varied from 49.9 to $95.7 \%$.
Though, more than $95.0 \%$ used mask when they went outside and avoid shaking hands with others, $32.1 \%$ indulged in face-to-face chatting with friends in groups both within and outside their residences and $16.5 \%$ did go to restaurants with friends and family. Knowledge, attitude and practice scores of students by demographic characteristics were also calculated (table III).

Table III: Knowledge, attitude and practice scores of students towards COVID -19 by demographic characteristics(n=399)

\begin{tabular}{|c|c|c|c|c|c|c|c|}
\hline \multirow{2}{*}{\multicolumn{2}{|c|}{ Variable }} & \multicolumn{2}{|c|}{ Knowledge score } & \multicolumn{2}{|c|}{ Attitude score } & \multicolumn{2}{|c|}{ Practice score } \\
\hline & & Mean \pm SD & Significance & $\operatorname{Mean} \pm$ SD & Significance & $\operatorname{Mean} \pm$ SD & Significance \\
\hline \multirow{4}{*}{ Age (years) } & $18-20$ & $11.31 \pm 1.44$ & & $2.17 \pm 0.60$ & & $5.61 \pm 1.28$ & \\
\hline & $21-23$ & $11.07 \pm 1.73$ & $\mathrm{~F}=3.288$ & $1.90 \pm 0.71$ & $\mathrm{~F}=5.838$ & $4.92 \pm 1.54$ & $\mathrm{~F}=8.297$ \\
\hline & $24-26$ & $10.83 \pm 1.71$ & $\mathrm{p}=0.021 * *$ & $1.88 \pm 0.78$ & $\mathrm{p}=0.001^{* *}$ & $4.94 \pm 1.86$ & $\mathrm{p} \leq 0.001 * *$ \\
\hline & $>26$ & $12.13 \pm 0.99$ & & $2.27 \pm 0.59$ & & $6.00 \pm 1.07$ & \\
\hline \multirow{2}{*}{ Gender } & Male & $11.07 \pm 1.59$ & $\mathrm{t}=-1.758$ & $1.98 \pm 0.68$ & $\mathrm{t}=-1.955$ & $5.04 \pm 1.58$ & $\mathrm{t}=-3.828$ \\
\hline & Female & $11.36 \pm 1.60$ & $\mathrm{p}=0.079$ & $2.11 \pm 0.69$ & $\mathrm{p}=0.053$ & $5.63 \pm 1.31$ & $\mathrm{p} \leq 0.001 * *$ \\
\hline \multirow{3}{*}{ Religion } & Islam & $11.17 \pm 1.84$ & \multirow{3}{*}{$\begin{array}{l}F=1.564 \\
p=0.211\end{array}$} & $2.02 \pm 0.69$ & \multirow{3}{*}{$\begin{array}{l}F=0.068 \\
p=0.938\end{array}$} & $5.2 \pm 1.50$ & \multirow{3}{*}{$\begin{array}{l}F=2.568 \\
p=0.078\end{array}$} \\
\hline & Hinduism & $11.37 \pm 1.52$ & & $2.04 \pm 0.66$ & & $5.71 \pm 1.40$ & \\
\hline & Others & $10.40 \pm 2.17$ & & $2.10 \pm 0.74$ & & $5.30 \pm 1.57$ & \\
\hline \multirow{3}{*}{$\begin{array}{l}\text { Educational } \\
\text { institution } \\
\text { type }\end{array}$} & Med College ${ }^{1}$ & $11.53 \pm 1.40$ & \multirow{3}{*}{$\begin{array}{c}\mathrm{F}=6.123 \\
\mathrm{p}=0.002 * *\end{array}$} & $2.26 \pm 0.55$ & \multirow{3}{*}{$\begin{array}{c}\mathrm{F}=16.635 \\
\mathrm{p} \leq 0.001 * *\end{array}$} & $5.63 \pm 1.33$ & \multirow{3}{*}{$\begin{array}{c}\mathrm{F}=9.907 \\
\mathrm{p} \leq 0.001 * *\end{array}$} \\
\hline & Pub Unv ${ }^{2}$ & $10.95 \pm 1.55$ & & $1.92 \pm 0.66$ & & $5.18 \pm 1.45$ & \\
\hline & Pvt Unv ${ }^{3}$ & $10.95 \pm 1.93$ & & $1.80 \pm 0.84$ & & $4.73 \pm 1.76$ & \\
\hline
\end{tabular}

1 Med College $=$ Medical college; 2 . PubUnv= Public University; 3.Pvt. Unv= Private University

**Statistically significant

The mean knowledge, attitude and practice score for medical students were found to be significantly higher compared to that for non-medical students (table-IV).

Table IV: Comparison of knowledge, attitude and practice scores between medical and non-medical students

\begin{tabular}{cccc}
\hline Variable & $\begin{array}{c}\text { Medical } \\
(\mathbf{1 5 2})\end{array}$ & $\begin{array}{c}\text { Non Medical } \\
(\mathbf{2 4 7})\end{array}$ & Test of significance \\
\hline Knowledge score & $11.53 \pm 1.40$ & $10.96 \pm 1.68$ & $\mathrm{t}=3.500 p=0.001^{* *}$ \\
Attitude score & $2.26 \pm 0.55$ & $1.88 \pm 0.72$ & $\mathrm{t}=5.591 p \leq 0.001^{* *}$ \\
Practice score & $5.63 \pm 1.33$ & $5.04 \pm 1.56$ & $\mathrm{t}=3.827 p \leq 0.001^{* *}$ \\
\hline
\end{tabular}

** Statistically significant

Among the students $52.1 \%$ had good knowledge, $22.8 \%$ had favourable attitude and $48.6 \%$ had good practices (table V).
Poor knowledge, unfavourable attitude and bad practice were significantly higher among nonmedical students compared to medical students.

Table V: Comparison of knowledge, attitude and practice categories by student type $(n=399)$

\begin{tabular}{|c|c|c|c|c|c|}
\hline \multirow{2}{*}{\multicolumn{2}{|c|}{ Variable }} & \multicolumn{3}{|c|}{ Student category ${ }^{\star}$} & \multirow{2}{*}{ Test of significance } \\
\hline & & Medical & Non-medical & Total & \\
\hline \multirow{2}{*}{ Knowledge } & Good $(=>11.2)$ & $\begin{array}{c}89 \\
(58.6)\end{array}$ & $\begin{array}{c}102 \\
(41.3)\end{array}$ & $\begin{array}{c}208 \\
(52.1)\end{array}$ & \multirow{2}{*}{ Chi squared value $=11.229$, df $1 ; \mathrm{p}=0.001^{* *}$} \\
\hline & $\begin{array}{c}\text { Poor } \\
(<11.2)\end{array}$ & $\begin{array}{c}63 \\
(44.1)\end{array}$ & $\begin{array}{c}145 \\
(58.7)\end{array}$ & $\begin{array}{c}191 \\
(47.9)\end{array}$ & \\
\hline Attitude & $\begin{array}{c}\text { Favorable }(=>2.4) \\
\text { Disfavor able } \\
(<2.4)\end{array}$ & $\begin{array}{c}48 \\
(31.6) \\
104 \\
(68.4)\end{array}$ & $\begin{array}{c}43 \\
(17.4) \\
204 \\
(82.6)\end{array}$ & $\begin{array}{c}91 \\
(22.8) \\
308 \\
(77.2)\end{array}$ & Chi squared value $=10.732$, df $1 ; p=0.001^{* *}$ \\
\hline Practice & $\begin{array}{c}\text { Good }(=>5.6) \\
\text { Bad } \\
(<5.6)\end{array}$ & $\begin{array}{c}91 \\
(59.9) \\
61 \\
(40.1)\end{array}$ & $\begin{array}{c}103 \\
(41.7) \\
144 \\
(58.3)\end{array}$ & $\begin{array}{c}194 \\
(48.6) \\
205 \\
(51.4)\end{array}$ & Chi squared value $=12.433$, df $1 ; \mathrm{p} \leq 0.001^{* *}$ \\
\hline
\end{tabular}




\section{Discussion}

Empowering the population with correct and adequate knowledge in the care and maintenance of their health actively often plays a remarkable role in disease prevention and control. As SARS-CoV-2 has caused a global pandemic of the century, it is important to encourage different population groups to adopt precautionary behaviors based on correct knowledge. Many studieshave examined the various levels of KAP about COVID-19 and limited information on KAP relating to COVID-19 was available..$^{12,16,18-25}$ Currently,the country is bringing forward normalcy in daily life and is resuming different economic activities, opening offices and looking forward to open up educational institutions at the proper moment. Therefore, a web-based survey conducted to assess KAP of students relating to COVID-19 to provide baseline data to government taking up measures for prevention of future COVID outbreaks and keeping it down to a manageable level.This study revealed that more than $90 \%$ of the students had knowledge about the symptoms of COVOD-19 and availability of the vaccine. Of them, $76.4 \%$ knew about the nonavailability of effective treatment.These findings were almost similar to that of Alzoubi et al.$^{20}$ The mean knowledge score of the students was $11.18 \pm 1.60$ and was significantly higher for medical students $(11.53 \pm 1.40)$ than for non-medical students (10.96 \pm 1.68 ), about $52.1 \%$ of the students in the current study had good knowledge, compared to nonmedical students (41.3\%) significantly higher proportion medical students of $(58.6 \%)$ was found to have good knowledge. Alzoubi et al did not find any significant difference regarding knowledge between medical and non-medical students in Jordan. ${ }^{20}$

A little more than $14 \%$ believed that smoking could prevent COVID-19 and only $29 \%$ believed that use of 3-layered cloth mask could prevent infection under general circumstances. The attitude score of the students was found to be $2.02 \pm 0.69$ and was significantly higher for medical students $(2.26 \pm 0.55)$ than for non-medical students (1.88 \pm 0.72 ). Moreover, attitude favourable for prevention/combatting disease was extremely low $(22.8 \%)$ among the students, and was significantly lower among non-medical students $(17.4 \%)$ in comparison to medical students (31.6\%). Alzoubi et al observed similar findings about smoking but did not find any significant difference regarding attitude between medical and non-medical students in Jordan. ${ }^{20}$ The practice scores for the student participants of this study was5.26 \pm 1.507 and it was significantly higher in medical $(5.63 \pm 1.33)$ than in non-medical students $(5.04 \pm 1.56)$. Good practice was prevalent in $48.6 \%$ of the participants, and it was significantly higher in medical students (59.9\%) compared to non-medical students $(41.7 \%)$. The Jordan study displayed favorable practices towards COVID-19 prevention such as hand washing, refraining from shaking hands, etc. ${ }^{20}$ However, in the current study, the students were found to be continuing handshakes $(10.8 \%)$ with others, to chat face-to-face $(31.5 \%)$ and even visits with friends and family $(16.5 \%)$ this possibly was because of the care free nature of the youths.

\section{Conclusion}

The current study revealed that there was urgent need to foster appropriate knowledge, positive attitude and practices towards prevention of COVID-19 among students in Bangladesh before reopens the educational institutions. The findings of this study are expected to help the policy maker about better planning for effective awareness campaigns targeting the specific group through well-planned and appropriate strategies. Hence the study result was based on limited sample size could not be generalised to all the students of Bangladesh. However, the study might be helpful in conducting further research of this kind.

\section{Conflict of interest: None}

Funding:None

Ethical approval: IRB of the Institute of Public Health, Dhaka

Submitted: $12^{\text {th }}$ October, 2020

Final revision received: $22^{\text {nd }}$ November, 2020

Accepted: $25^{\text {th }}$ November, 2020

Published: $1^{\text {st }}$ December, 2020

\section{References}

1. Lu R, Zhao X, Niu P, Yang B, Wu h, et al Genomic characterization and epidemiology of 2019 novel coronavirus: Implications for virus origin and receptor binding. Lancet. 2020; 395:565-574

2. Riou J, AlthausCl, Pattern of early human-tohuman transmission of Wuhan 2019 novel coronavirus (2919-n CoV), December 2019 to January 2020. Euro Surveill, 2020; 25:2000058. DOI: 10.2807/1560-7917. ES.2020.25.4.200005.8 
3. WHO announces COVID-19 outbreak a pandemic. 12 March 2020

URL: www.euro. who.int/en/health-topics/healthemergencies/coronavirus - covid-19/news/news/ 2020/3/who - announces- covid -19- outbreaka-pandemic

4. Rahman SMM, Akter A, Mostari KF, Ferdousi S, Ummon IJ, Maafi SM et al. Assessment of knowledge, attitudes and practices towards prevention of corronavirus disease (COVID-19) among Bangladeshi Population. Bangladesh Med Res Counc Bull. 2020; 46: 73-82.

DOI: 103329/bmrc.v46i2.49015

5. Walker PGT, Whittaker C, Watson O, Baguelin M, Ainslie KEC, Bhatia S, et al. The Global Impact of COVID-19 and Strategies for Mitigation and Suppression. Imperial College London, 2020 DOI: $10.25561 / 77735$

6. Acter T, Uddin N, Das J, Akhter A, Choudhury TR, Kim S. Evolution of severe acute respiratory syndrome coronavirus 2 (SARS-CoV-2) as coronavirus disease 2019 (COVID-19) pandemic: A global health emergency. Sci Total Environ. 2020: 15;730:138996.

DOI: $10.1016 /$ j.scitotenv.2020.138996.

7. WHO. Report of the WHO-China Joint Mission on coronavirus Disease 2019 (COVID-19), 2020a.

URL:www.who.int/publications/i/item/report-ofthe-who-china-joint-mission-on-coronavirusdisease-2019-(covid-19)

8. Zhou P, Yang Xl, Wang XG, Hu B, Zhang L, Zhang $\mathrm{W}$ et al. A pneumonia outbreak associated with a new coronavirus of probable bat origin. Nature, 2020; 579: 270-273.

DOI: $10.1038 / \mathrm{s} 41586-020-2012-7$

9. WHO. Cleaning and disinfection of environmental surfaces in the context of COVID19. Interim guidance, 15 May 2020b. URL:www.who.int/publications/i/item/cleaningand-disinfection-of-environmental-surfacesinthe-context-of-covid-19

10. Fang L, Karakiulakis G, Roth M. Are patients with hypertension and diabetes mellitus at increased risk for COVID-19 infection? Lancet Respir Med. 2020: 8: e21 DO: $10.1016 / \mathrm{S} 2213-2600(20) 30116-8$

11. JinYh, Cai L, Cheng Z3S, Cheng H, Deng T, Fan YP, et al. A rapid advice guideline for the diagnosis and treatment of 2019 novel coronavirus (2019- nCOV) infected pneumonia (Standard version). Mil Med Res. 2020; 7:4. DOI: 10.1186/s40779-0233- 6

12. Maheshwari S, Gupta PK, Sinha R, and Rawat P. Knowledge, attitude and practices towards coronavirus disease-2019 (COVID -19) among Medical students: A cross-sectional study. J Acute Dis.2020;9:100-104.

DOI: $10.4103 / 2221-6189.283886$

13. 312 Bangladeshis return from China. Independent Online/BSS Published by Independent Publications Limited at Media Printers, 446/H, Tejgaon I/A, Dhaka-1215. Beximco Media Complex, 149-150 Tejgaon I/A, Dhaka-1208, Bangladesh. GPO Box No. 934, Dhaka1000. MODIFIED: 2 February, 2020 09:19:08 AM

14. Bangladesh confirms first three coronavirus cases. Somoy English Desk. 2020 March 16:20. URL:en.somoynews.tv/5897/news/Bangladeshconfirms-first-three-coronavirus cases

15. Hossain I, Khan MH, Ahmad SA, Rahman MS,Mullick AR, Aktaruzzaman MM. The Epidemiological Characteristics of an Outbreak of 2019 Novel Coronavirus Diseases (COVID19) In Bangladesh: A Descriptive Study. JMSCR. 2020: 544-51

DOI: $10.18535 / \mathrm{jmscr} / \mathrm{v} 8 \mathrm{i} 4.94$

16. Geldsetzer P. Knowledge and precautions of COVID-19 among the general public in the United States and the United Kingdom: a crosssectional online survey. Ann Intern Med. 2020: M20-0912

DOI:10.7326/M20-0912

17. Khasawneh AI, Humeidan AA, Alsulaiman JW, Bloukh S, Ramadan M, Al-Shatanawi TN, et al. Medical Students and COVID-19: Knowledge, Attitudes, and Precautionary Measures. A Descriptive Study From Jordan. Frontiers in Public Health. 2020;8: 253. URL:www.frontiersin.org/article/10.3389/fpubh. 2020.00253

18. Rahman A, Sathi NJ. Knowledge, Attitude, and Preventive Practices toward COVID-19 among Bangladeshi Internet Users. Electron J Gen Med. 2020;17:em245.

DOI: $10.29333 /$ ejgm/8223

19. Olum R, Chekwech G, Wekha G, Nassozi DR, Bongomin F. Coronavirus Disease-2019: Knowledge, Attitude, and Practices of Health Care Workers at Makerere University Teaching Hospitals, Uganda. Front Public Health. 2020: 8:181. DOI: 10.3389/fpubh.2020.00181.

20. Alzoubi H, Alnawaiseh N, Al-Mnayyis A, Lubada MA, Aqel A and Al-Shagahin H. COVID-19 Knowledge, Attitude and Practice among Medical and Non-Medical University Students in Jordan. J Pure Appl Microbiol.2020; 14: 17-24 DOI: $10.22207 /$ JPAM.14.1.04 
21. Huyan G, Nguyen TNH, Tran VK, Vo KN, Vo VT, Pham LA. Knowledge and attitude towards COVID-19 among healthcare workers at District 2 Hospital, Ho Chi Minh City.Asian Pacific J Trop Med 2020; 13:260-265.

DOI: $10.4103 / 1995-7645.280396$

22. Lin $\mathrm{Y}$, Huang $\mathrm{L}, \mathrm{Nie} \mathrm{S}$, et al. Knowledge, attitudes and practices (KAP) related to the pandemic (H1N1) 2009 among Chinese general population: a telephone survey. BMC Infect Dis. 2011;11:128.

DOI:10.1186/1471-2334-11-128
23. Karim A, Akter M, Mazid AT, et al. Knowledge and attitude towards COVID-19 in Bangladesh: Population-level estimation and a comparison of data obtained by phone and online survey methods. medRxiv; 2020. Accessed at medrxiv.org DOI: 10.1101/2020.05.26.20104497.

24. Paul A, Sikdar D, Hossain MM, Amin MR, Deeba F, Mahanta J, et al. Knowledge, attitudes, and practices toward the novel coronavirus among Bangladeshis: Implications for mitigation measures. PLoS ONE. 2020: 15: e0238492. DOI: 10.1371/journal.pone.0238492 